AGRITECH, Vol. 37, No. 3, Agustus 2017, Hal. 327-333

DOI: http://doi.org/10.22146/agritech.10697 ISSN 0216-0455 (Print), ISSN 2527-3825 (Online) Tersedia online di https://jurnal.ugm.ac.id/agritech/

\title{
Tingkat Kelarutan Peptida Tempe dengan Bobot Molekul Kecil pada Berbagai Jenis Pelarut
}

\author{
The Solubility of Low Molecular Weight Peptides from Tempe in Different Solvents \\ R. Rusdah ${ }^{1 \star}$, Maggy Thenawidjaya Suhartono ${ }^{1}$, Nurheni Sri Palupi', Masahiro Ogawa ${ }^{2}$ \\ ${ }^{1}$ Jurusan Ilmu Pangan, Fakultas Teknologi Pertanian, Institut Pertanian Bogor, Jl. Raya Dramaga, Bogor 16680, Indonesia \\ ${ }^{2}$ Food Science, Kagawa University of Agriculture, Miki-Kagawa 761-0795, Japan \\ E-mail: kalila.thalib@gmail.com,mthenawidjaja@yahoo.com
}

Submisi: 25 April 2016; Penerimaan: 21 September 2016

\begin{abstract}
ABSTRAK
Metode ekstraksi peptida terlarut pada produk kedelai dan fermentasi kedelai sangat bervariasi. Penelitian ini dilakukan untuk menganalisa sifat kelarutan peptida dengan berat molekul kecil pada sampel tempe yang diambil dari dua jenis kedelai (GMO dan non-GMO) serta dua jenis perlakuan (perebusan dan tanpa perebusan) yang berbeda. Pelarut yang digunakan meliputi air dan pelarut organik yang umum digunakan dalam ekstraksi peptida kedelai dan produk fermentasinya. Hasil penelitian menunjukkan bahwa pelarut organik asetonitril: air: asam trifluoroasetat (A1W1TF) memberikan tingkat kelarutan peptida tempe kedelai lebih baik dibanding pelarut air $(p<0,05)$. Penambahan asam trifluoroasetat pada pelarut campuran asetonitril-air (A1W1) terbukti meningkatkan peptida terlarut hingga $1,522 \mathrm{mM}$ $(31,7 \%)$. Tempe GMO menunjukkan kelarutan peptida lebih tinggi dibanding non-GMO sedangkan proses perebusan juga diketahui mempunyai tingkat kelarutan yang lebih tinggi dibanding tempe tanpa perebusan.
\end{abstract}

Kata kunci: Asetonitrile; kelarutan; peptida; tempe; asam trifluoroasetat

\begin{abstract}
There are various methods exist to extract soluble peptide from soybean and its fermented products. This study was aimed to evaluate the solubility of low molecular weight peptide of tempe from two types of bean (GMO and non-GMO soybean) and two different treatment (boiling and non-boiling). The solvents used were water and organic solvents which commonly used as solvents for soy-fermented product. The result showed that acetonitrile (A): water (W): trifluoroacetic acid (TF) provided higher solubility of the peptides compared with water $(p<0.05)$. The addition of trifluoroacetic acid in acetonitrile-water mixture (A1W1) increased the peptide recovery about $1.522 \mathrm{mM}(31.7 \%)$. The GMO tempe showed the higher content of peptide recovery compared with non-GMO tempe, while boiled tempe also gave higher peptide recovery than non-boiled tempe.
\end{abstract}

Keywords: Acetonitrile; GMO; peptide; recovery; tempe; trifluoroacetic

\section{PENDAHULUAN}

Tempe merupakan salah satu pangan produk fermentasi kedelai (Glycine max L.) berasal dari Indonesia yang saat ini sudah dikenal luas didunia. Pada perkembangannya, tempe bisa diproduksi menggunakan berbagai jenis kacang seperti kacang koro benguk (Mucuna pruriens L.D.C. var. utilis), gude (Cajanus cajan), lupin (Lupinus angustifolius), kacang merah (Phaseolus vulgaris) dan jenis lainnya, namun kedelai merupakan jenis bahan baku yang paling populer dikarenakan 
ketersediaan bahan yang melimpah, keunggulan rasa dan juga tekstur yang membentuk cita rasa khas tempe. Indonesia mempunyai tingkat konsumsi tempe mencapai $7 \mathrm{~kg}$ / kapita / tahun dan sekitar $60 \%$ dari total konsumsi kedelai nasional diproses menjadi tempe (Soim, 2013).

Kedelai mengandung sekitar $20-40 \%$ (basis berat kering) protein. Proses fermentasi kedelai menggunakan Rhizopus sp. dapat meningkatkan kandungan asam amino dan peptida yang berpotensi sebagai peptida bioaktif (Amadou dkk., 2010; Fan dkk., 2009; Mahmod dkk., 2011; Wang dkk., 2003; Zhang dkk., 2006). Peptida bioaktif merupakan fragmen peptida spesifik (2 - 42 asam amino) yang dapat memberikan beberapa keuntungan terhadap tubuh manusia diantaranya sebagai antioksidan, antihipertensi, dan antikanker (Singh dkk., 2014). Keberadaan peptida bioaktif ini bisa sangat bervariasi tergantung pada karakteristik bahan dan tipe pengolahan yang diberikan (Nakahara dkk., 2012). Perbedaan karakter peptida yang dihasilkan pada produk fermentasi kedelai menyebabkan pemilihan ekstraksi peptida menjadi sangat spesifik untuk masing-masing bahan.

Ekstraksi peptidabioaktifprodukfermentasikedelaitelah banyak dilakukan dan diketahui bahwa karakter fisikokimia dan struktural bahan seperti kelarutan, berat molekul dan hidrofobisitas menjadi hal yang penting dalam menentukan pelarut ekstraksi terbaik. Penggunaan air (Chertov dkk., 2004; Gibbs dkk., 2004; Handoyo dan Morita, 2006; Matsuo, 2006; Wang dkk., 2006; Zhu dkk., 2008; Mahmod dkk., 2011) dan pelarut organik pada produk fermentasi kedelai seperti natto, doenjang dan tempe merupakan dua tipe pelarut yang umum digunakan dalam ekstraksi komponen larut air termasuk peptida (Amadou dkk., 2009). Pelarut organik memiliki keunggulan diantaranya kemampuan untuk mengendapkan protein induk dan komponen lemak sehingga meningkatkan daya larut peptida dengan berat molekul rendah (Natarajan dkk., 2009; Du dkk., 2014).

Pengaruh karakter bahan terhadap sifat kelarutan menyebabkan pemilihan jenis pelarut untuk ekstraksi haruslah dilakukan secara spesifik untuk masing-masing bahan. Penelitian ini akan mengevaluasi beberapa jenis pelarut organik dibandingkan dengan pelarut air terhadap tingkat kelarutan peptida. Tempe yang digunakan berasal dari jenis kedelai GMO yang merupakan jenis paling umum dalam pembuatan tempe, serta non-GMO yang menjadi brand baru untuk pasar konsumen Indonesia yang menghindari produk GMO. Kedelai GMO diduga memiliki kandungan asam amino yang berbeda dengan kedelai non-GMO, sehingga penelitian mengenai perbedaan kelarutan peptida pada tempe GMO dan non-GMO menarik untuk dilakukan. Efek proses perebusan terhadap sifat kelarutan peptida tempe juga ikut diamati dikarenakan tempe harus melalui proses pengolahan terlebih dahulu sebelum dikonsumsi. Sifat kelarutan peptida bioaktif tempe pada produk yang telah melalui proses pemasakan dan studi pembandingan beberapa jenis pelarut belum pernah dilakukan sehingga penelitian ini akan mampu secara spesifik mengevaluasi proses pengolahan, tipe kedelai terhadap kelarutan peptida pada beberapa jenis pelarut.

\section{METODE PENELITIAN}

\section{Bahan dan Alat}

Bahan yang digunakan dalam penelitian ini adalah tempe kedelai (Glycine max L.) yang diambil dari salah satu rumah produksi tempe di Bogor, Jawa Barat yang terdiri dari dua jenis tempe yakni tempe kedelai GMO dan tempe non-GMO. Reagen yang digunakan diantaranya adalah O-pthalaldehyde (OPA), asam amino glycine (Gly), albumin (bovine serum Cohn $\mathrm{V}$ fraction) (BSA), membran filtrasi (1.000; 3.500-6.000; dan 8.000 MWCO), etanol 99,5\% (Wako Pure Chemicals Industries, Japan), acetonitril 99,8\%, sodium dodecyl sulphate (SDS), coomassie blue R-250, trifluoroacetic acid, pre-stained protein marker (broad range) untuk SDS PAGE (Nacalai tesque, Japan). Semua jenis reagen yang digunakan dalam studi ini merupakan bahan kimia analitik. Sedangkan peralatan utama yang digunakan meliputi sentrifuse dingin (Thermofisher, Japan), waterbath (Taitec, Japan), spektrofotometer (Jasco, Japan), dan glassware.

\section{Tahapan Penelitian}

Penelitian ini dibagi menjadi dua tahap yaitu penentuan jenis pelarut terbaik dengan 7 jenis pelarut organik yakni ; 1) acetonitril (1): air (1) (A1W1), 2) acetonitril (1): air (3) (A1W3), 3) acetonitril (3): air (1) (A3W1), 4) acetonitril (1): air (1): $10 \%$ trifluoroacetic acid (TFA) dalam air $(0,02)$ (A1W1TF), 5) etanol (ETA), 6) 0,01\% TFA dalam air, dan 7) air distilat (DW), menggunakan satu jenis sampel dari tempe kedelai (GMO) sebagai representasi. Pelarut dengan hasil kelarutan peptida terbaik kemudian di gunakan untuk perbandingan ekstraksi dengan air pada semua sampel uji.

\section{Ekstraksi}

Tempe segar yang baru diproduksi diambil dan dikelompokkan berdasarkan jenis dan perlakuan yakni: 1) tempe GMO, tanpa perebusan; 2) tempe GMO, dengan perebusan; 3) tempe non-GMO, tanpa perebusan; 4) tempe non-GMO, dengan perebusan. Teknik perebusan tempe dilakukan dengan memasukkan tempe yang telah dipotong dengan ukuran sama $(6 \times 2 \mathrm{~cm})$ kedalam air mendidih dan dibiarkan sampai 10 menit. Tempe yang telah diproses sesuai perlakuan kemudian dikeringkan menggunakan freeze drying dan disimpan pada suhu $-20{ }^{\circ} \mathrm{C}$ hingga digunakan untuk analisa. Masing-masing sampel diekstraksi dengan dua jenis pelarut yakni; 1) air distilat, dan 2) pelarut organik. 
Sebanyak $1 \mathrm{~g}$ sampel dicampur dengan $30 \mathrm{~mL}$ pelarut, kemudian dilakukan sonikasi selama 5 menit dan di maserasi pada shaker waterbath suhu $30^{\circ} \mathrm{C}$ selama 60 menit. Larutan kemudian disaring menggunakan kertas saring Nacalai Tech. No 1 dan dilanjutkan dengan sentrifugasi pada 10,000 xg, 45 menit. Filtrat yang didapat kemudian di pekatkan menggunakan evaporator vakum $\left(80{ }^{\circ} \mathrm{C}, 3\right.$ jam $)$. Filtrat kemudian disimpan dalam suhu $-20{ }^{\circ} \mathrm{C}$ sampai dilakukan analisa.

\section{Kelarutan Peptida}

Protein merupakan kumpulan peptida yang tersusun oleh minimal 2 asam amino melalui sebuah ikatan kovalen. Kumpulan polimer peptida rantai panjang akan menyusun protein. Tingkat kelarutan peptida dalam pelarut dilakukan dengan metode $O$-pthalaldehyde (OPA) yang berbasis pada keberadaan asam amino bebas (Mahmod dkk., 2011). Reagen OPA disiapkan dengan mencampur $80 \mathrm{mg}$ of $O$-phthalaldehyde, $2 \mathrm{~mL}$ metanol, $50 \mathrm{~mL}$ dari $0,1 \mathrm{M}$ sodium tetraborate $\left(\mathrm{Na}_{2} \mathrm{~B}_{4} \mathrm{O}_{7}\right), 5 \mathrm{~mL}$ dari $20 \%(\mathrm{w} / \mathrm{v}) \mathrm{SDS}$, dan $0,2 \mathrm{~mL}$ $\beta$-mercaptoethanol. Sebanyak $150 \mu \mathrm{L}$ sampel atau larutan standard dicampur dengan 3,0 $\mathrm{mL}$ reagen OPA. Campuran kemudian didiamkan selama 2 menit pada suhu ruang kemudian dihitung absorbansinya secara tepat pada $340 \mathrm{~nm}$. Tingkat kelarutan peptida dihitung berdasarkan kurva standar glycine $(0,005-1,00 \mathrm{mM})$.

\section{SDS PAGE}

SDS-PAGE dilakukan mengikuti metode Fling dan Gregerson (1986) dengan modifikasi menggunakan konsentrasi $4 \%$ gel penahan dan 12,5\% gel pemisah. Ekstrak protein $(12,5 \mu \mathrm{L})$ dicampur dengan SDS sample buffer $(50$ $\mu \mathrm{L}$ ) (mengandung 0,055 M Tris-HCl, $\mathrm{pH} 6,8,2 \% \mathrm{SDS}(\mathrm{wt} /$ vol), $7 \%$ glycerol (wt/vol), 4,3\% $\beta$-mercaptoethanol, $0,0025 \%$ (wt/vol) commassie blue), dipanaskan pada $100{ }^{\circ} \mathrm{C}$ selama 2 menit dan didiamkan hingga mencapai suhu ruang. Sebanyak $15 \mu \mathrm{L}$ larutan dan $5 \mu \mathrm{L}$ marker SDS-PAGE diinjeksikan ke dalam gel dan dijalankan pada $17 \mathrm{~mA}$ selama kurang lebih 2 jam atau hingga sampel telah mencapai batas akhir gel. Gel di rendam dalam larutan Coomassie Blue R-25 (mengandung $3,9 \%(\mathrm{v} / \mathrm{v})$ trifluoroacetic acid, $6 \%(\mathrm{v} / \mathrm{v})$ acetic acid, dan $17 \%$ metanol) selama 30 menit dan dicuci dengan larutan $10 \%$ acetic acid dan 18\% etanol dalam air selama 6 jam.

\section{Analisis Data}

Analisis data menggunakan software SPSS (version 16.0) dengan uji lanjut Duncan dan Tukey.

\section{HASIL DAN PEMBAHASAN}

\section{Efek Pelarut terhadap Tingkat Kelarutan Peptida}

Tingkat kelarutan peptida berdasarkan pada karakter fisik dan kimia yang bisa sangat bervariasi. Beberapa studi melaporkan pengaruh $\mathrm{pH}$ pelarut, suhu, dan tipe pelarut memberi pengaruh besar terhadap kelarutan peptida yang berasal dari kedelai (Pace dkk., 2004). Gambar 1 menunjukkan data kelarutan protein dari berbagai jenis pelarut menggunakan sampel tempe GMO tanpa perlakuan pemasakan. Pelarut organik seperti acetonitril dan trifluoroacetic acid menunjukkan tingkat kelarutan peptida yang lebih tinggi khususnya pada produk kedelai dan olahannya (Matsuo, 2006; Shon dkk., 2007; Natarajan dkk., 2009), disamping itu, air masih menjadi jenis pelarut yang banyak digunakan untuk ekstraksi sehubungan dengan karakter kelarutannya yang umum (Chertov dkk., 2004; Handoyo dan Morita, 2006; Matsuo, 2006; Wang dkk., 2006; Zhu dkk., 2008).

Tingkat kelarutan peptida berdasar nilai gugus asam amino bebas berbeda signifikan $(p<0,05)$ pada pelarut A1W1; A1W3; A3W1; A1W1TF; DW, sedangkan pelarut etanol dan 0, 01\% TFA tidak berbeda signifikan terhadap A1W1 dan A1W3. Tingkat kelarutan protein bervariasi mulai dari 1,897-4,708 $\mathrm{mM}$ dengan hasil kelarutan tertinggi didapat pada A1W1TF diikuti oleh A1W3; ETA; A1W1; DW; 0, 01\% TFA dan A3W1. Kelarutan paling tinggi diperoleh pada pelarut A1W1TF, diduga disebabkan karakter pelarut yang memiliki derajat hidrofobisitas moderat sehingga mampu mengendapkan protein dengan berat molekul besar dan meningkatkan kelarutan peptida. Tingkat hidrofobisitas yang dimiliki pelarut memiliki pengaruh dalam meningkatkan interaksi antar molekul hidrofobik pada protein dan memicu agregasi.

Kelarutan paling rendah ditemukan pada penggunaan pelarut A3W1, hal ini dimungkinkan karena konsentrasi acetonitril dalam air yang terlalu tinggi. Pada sistem pelarut campuran acetonitril-air ditemukan bahwa peningkatan kandungan acetonitril tidak berbanding lurus dengan

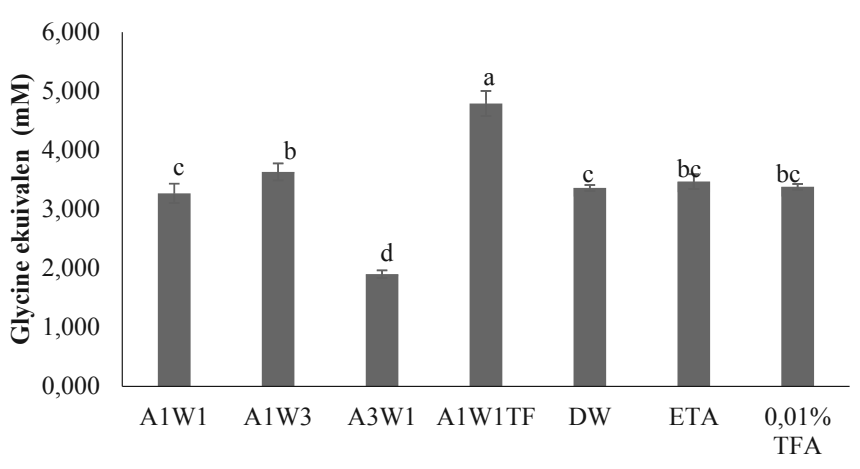

Gambar 1. Kelarutan peptida tempe pada berbagai jenis pelarut 
peningkatan kelarutan peptida, sebaliknya penambahan volume air pada pelarut A1W3 menunjukkan performa yang lebih baik dibandingkan dengan A3W1. Penggunaan acetonitrile dalam air pada proporsi yang sesuai dapat membantu meningkatkan kelarutan peptida, namun pada konsentrasi yang terlalu tinggi, acetonitrile justru menurunkan tingkat kelarutan peptida meskipun masih menunjukkan performa yang baik dalam mengendapkan protein dengan berat molekul tinggi (Chen dkk., 2007; Kay dkk., 2008; Kawashima dkk., 2010). Acetonitril diduga mempunyai kemampuan untuk melemahkan ikatan hidrofobik sehingga meningkatkan ikatan hidrogen internal protein dan membuat protein mengalami denaturasi (Gekko dkk., 1998).

Studi yang pernah dilakukan, larutan acetonitril dalam air dapat lebih baik mengekstrak peptida dengan berat molekul rendah pada sampel tempe dan natto dibandingkan dengan hanya menggunakan pelarut air maupun metanol (Mahmod dkk., 2011; Gibbs dkk., 2004). Penambahan trifluoacetic acid (TFA) pada pelarut campuran acetonitril-air diketahui mempunyai kepasitas untuk mendisosiasi peptida dari protein pembawa dan membuatnya menjadi lebih larut dalam pelarut (Chertov dkk., 2004; Alpert dan Shukla, 2003).

\section{Kelarutan Peptida Berbagai Jenis Tempe}

Tempe yang digunakan merupakan jenis tempe yang paling banyak diproduksi di Indonesia yakni tempe dengan kedelai GMO serta tempe kedelai yang memiliki pasar khusus yakni tempe dengan kedelai non-GMO (Suyantohadi, 2016). Hasil kandungan peptida terlarut pada semua jenis sampel tempe disajikan pada Gambar 2. Peptida pada tempe kedelai GMO menunjukkan tingkat kelarutan yang lebih tinggi dibandingkan dengan jenis tempe kedelai nonGMO pada pelarut air maupun A1W1TF. Perbedaan tingkat kelarutan ditemukan pada sampel tempe yang diproses dengan pengolahan dan tanpa pengolahan. Kelarutan peptida dari tempe kedelai GMO yang telah dilakukan perebusan

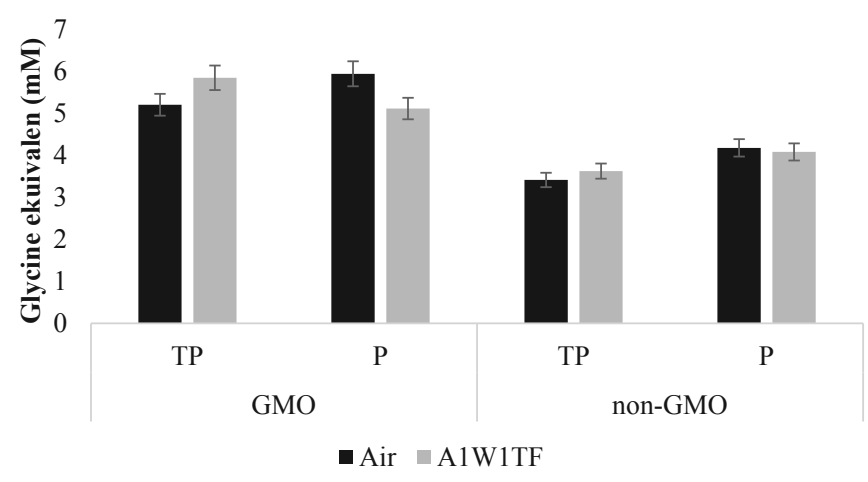

Gambar 2. Kelarutan peptida tempe pada pada sampel, tipe pengolahan dan pelarut berbeda

(a) $\mathrm{TP}=$ tanpa pengolahan, (b) $\mathrm{P}=$ perebusan selama 10 menit menggunakan pelarut air, menunjukkan kandungan peptida yang lebih tinggi dibandingkan dengan sampel tempe GMO tanpa proses perebusan. Hasil berbeda ditemukan pada ekstrak pelarut A1W1TF, dimana kelarutan peptida tempe yang telah direbus lebih rendah dibanding tempe yang tidak melalui proses perebusan. Sampel tempe non-GMO menunjukkan kelarutan peptida yang lebih besar pada tempe yang sudah melalui proses perebusan baik pada pelarut air maupun A1W1TF.

Tempe kedelai non-GMO saat ini mulai banyak dikembangkan dan mempunyai target pasar khusus yang peduli terhadap isu pangan dengan label modifikasi genetik. Produk GMO diduga memiliki perbedaan kandungan nutrisi diantaranya protein, sehingga penelitian mengenai perbedaan kelarutan peptida pada produk GMO dan non-GMO dapat menjadi langkah awal untuk mengenal dan menganalisis karakter protein dan peptida masing-masing.

Perbedaan peptida terlarut pada tempe GMO dan non-GMO cukup besar. Perbedaan ini bisa disebabkan oleh perbedaan karakter kelarutan peptida masing-masing sampel yang mempengaruhi kelarutan pada pelarut air dan A1W1TF. Perbedaan varietas dan masa panen diketahui mempengaruhi kandungan protein kedelai yang diolah pada menjadi tempe. Varietas detail kedelai yang digunakan pada penelitian ini tidak dapat dilacak sehingga data ini hanya akan sesuai pada jenis tempe kedelai yang diproduksi oleh salah satu rumah produksi tempe di Bogor yang menjadi sumber bahan baku.

Proses fermentasi dan pengolahan tempe menyebabkan perubahan fisik dan nutrisi. Perebusan, perendaman, dan fermentasi hingga proses perebusan tempe sebelum dikonsumsi menyebabkan perubahan asam amino, peptida dan protein (Chutipanyaporn dkk., 2014). Gibbs dkk. (2004) menemukan bahwa setelah proses fermentasi tempe, kandungan sebagian besar asam amino hidrofobik meningkat (Gly, Leu, Ile, Pro, Phe, Tryp) sebagian asam amino cenderung tetap (Ala, Val) sedangkan asam amino polar (Ser, Asp, Glu, Tyr) cenderung menurun. Perubahan komposisi asam amino dan peptida berpengaruh penting terhadap sifat kelarutan, pada penelitian ini, terjadinya perbedaan tingkat kelarutan tempe pada pada pelarut air dan A1W1TF diduga disebabkan oleh perbedaan sifat kimia asam amino dan peptida tempe.

\section{Berat Molekul Protein Tempe}

Acetonitril dan trifluoroacetic acid diketahui dapat melarutkan peptida dengan berat molekul rendah lebih baik dibandingkan dengan pelarut air (Natarajan dkk., 2009; Tirumalai, 2003; Mahmod dkk., 2011). Ekstrak sampel difraksinasi menggunakan gel SDS-PAGE untuk melihat berat molekul peptida yang terekstrak. Gambar 3 menunjukkan bahwa tidak ditemukan protein dengan berat molekul $>120$ 


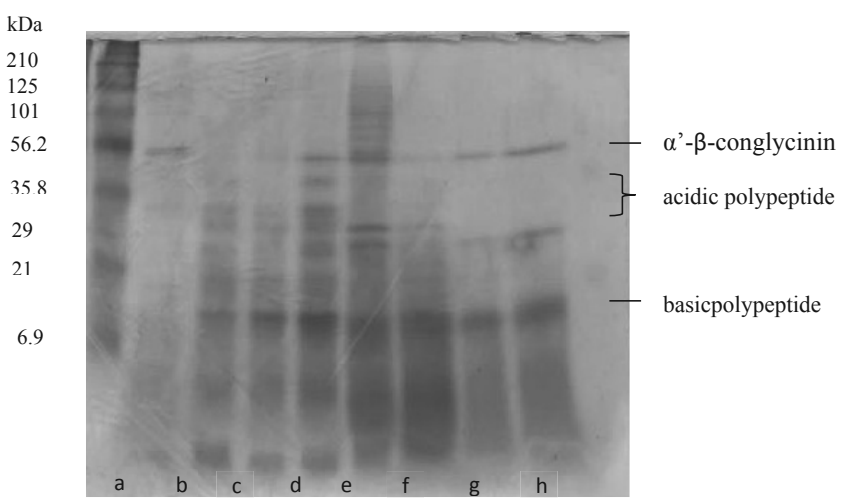

Gambar 3. SDS-PAGE; ekstrak air dari (a) a=tempe GMO (b) b=tempe GMO, perebusan, (c) c=tempe non-GMO (d) d=tempe nonGMO, perebusan; dan ekstrak AIWITF dari (e) e=tempe GMO, (f) $\mathrm{f}=$ tempe GMO, perebusan, (g) g=non-GMO tempe, (h) $\mathrm{h}=$ tempe non-GMO, perebusan

kDa baik pada ekstrak air maupun A1W1TF untuk semua jenis sampel.

Ekstrak air dari tempe non-GMO menunjukkan lebih banyak jenis protein yang berhasil diidentifikasi pada gel SDS-PAGE, dimana band paling banyak ditemukan pada tempe yang telah diproses dengan perebusan. Hal ini diduga disebabkan karena pemanasan menyebabkan pemecahan protein induk kedelai sehingga menghasilkan lebih banyak fraksi protein dengan berat molekul yang lebih rendah $(<$ $56,2 \mathrm{kDa}$ ). Perbedaan banyaknya jumlah band protein yang berhasil ditangkap gel SDS-PAGE pada ekstrak tempe GMO dan non-GMO menunjukkan jumlah yang tidak jauh berbeda, hasil ini senada dengan penelitian sebelumnya yang dilakukan Ichsani (2013) dimana kedelai non-GMO memiliki kandungan protein yang tidak berbeda signifikan dengan kedelai GMO. Perbedaan kandungan protein GMO dan nonGMO lebih didasarkan pada perbedaan varietas, dan faktorfaktor lain selama masa tanam.

Protein dengan berat molekul yang lebih tinggi (29-56,2 kDa) ditemukan pada ekstrak air sedangkan pada ekstrak A1W1TF hanya menunjukkan satu band protein pada $56,2 \mathrm{kDa}$ dan $<29 \mathrm{kDa}$ pada konsentrasi yang lebih rendah. Pelarut air dapat mengekstrak baik glycinin (11S) tipe acidic (31-45 kDa) dan basicpolipeptida (18-20 kDa) dibandingkan dengan A1W1TF. Hal ini diduga, A1W1TF mengandung lebih banyak peptida dengan berat molekul kecil $(<6,9 \mathrm{kDa})$ (band tidak tampak pada gel SDS-PAGE) dibandingkan dengan air. Protein dengan berat molekul paling besar yang berhasil dikonfirmasi oleh gel adalah $\alpha$ '- $\beta$-conglycinin $(56,2$ $\mathrm{kDa}$ ). Hasil ini menunjukkan bahwa A1W1TF mempunyai kemampuan lebih baik untuk mengekstrak peptida dengan berat molekul rendah.

\section{KESIMPULAN}

Penggunaan pelarut acetonitril: air: trifluoroacetic acid (A1W1TF) mampu meningkatkan kelarutan peptida pada sampel tempe kedelai dibandingkan dengan penggunaan pelarut tunggal air. Pelarut campuran acetonitril-air menunjukkan penambahan konsentrasi acetonitrile pada air justru menurunkan tingkat kelarutan peptida, sedangkan sebaliknya, pada konsentrasi acetonitrile yang lebih rendah (A1W3) dapat meningkatkan kelarutan peptida dibandingkan pada A1W1 dan A3W1. Trifluorocetic acid dalam konsentrasi rendah pada pelarut campuran A1W1 (A1W1TF) dapat meningkatkan kelarutan peptida secara signifikan. SDSPAGE mengkonfirmasi berat molekul protein dan peptida pada ekstrak air dan A1W1TF pada semua jenis sampel, menunjukkan bahwa A1W1TF mengekstrak peptida dengan berat molekul rendah $(<6,9 \mathrm{kDa})$ lebih baik dibandingkan dengan ekstrak air.

Jenis kedelai pada GMO dan non-GMO menunjukkan perbedaan tingkat kelarutan pada semua jenis pelarut dimana GMO memiliki kelarutan yang lebih tinggi. Sedangkan pengaruh pengolahan (perebusan) meningkatkan tingkat kelarutan protein dan juga menunjukkan lebih banyak fragmen peptida yang terdeteksi pada gel SDS-PAGE.

\section{UCAPAN TERIMA KASIH}

Penelitian ini didukung oleh beasiswa Lembaga Pengelola Dana Pendidikan RI (LPDP-RI) dan beasiswa joint degree oleh JASSO (Japan Students Service Organization), Jepang. Terima kasih kepada Prof. Dr. Masahiro Ogawa sebagai supervisor selama melakukan riset di laboratorium ilmu pangan, Kagawa University, Jepang.

\section{DAFTAR PUSTAKA}

Alpert, A.J. dan Shukla, A.K. (2003). Precipitation of large, high-abundance proteins from serum with organic solvents. The Association of Biomolecular Resource Facilities (ABRF): Translating biology using proteomics and functional genomics. Poster no. P111-W.

Amadou, I., Yong-Hui, S., Sun, J. dan Guo-Wei, L. (2009). Fermented soybean products: Some methods, antioxidants compound extraction and their scavenging activity. Asian Journal of Biochemistry 4(3): 68-76.

Amadou, I., Olasunkanmi, S., Gbadamosi, Yong- Hui Shi., Kamara, M.T., Sun Jin dan Ledan Guo-Wei (2010). Identification of antioxidative peptides from Lactobacillus plantarum Lp6 fermented soybean 
protein meal. Research Journal of Microbiology 5: 372-380.

Chen, J., Anderson, M., Misek, D.E., Simeone, D.M. dan Lubman, D.M. (2007). Characterization of apolipoprotein and apolipoprotein precursors in pancreatic cancer serum samples via two-dimensional liquid chromatography and mass spectrometry. Journal of Chromatography A 1162(2): 117-125.

Chertov, O., Biragyn, A., Kwak, L.W., Simpson, J.T., Boronina, T., Hoang, Van M., Prieto, DaRue A., Conrads, T.P., Veenstra, T.D. dan Fisher, R.J. (2004). Organic solvent extraction of proteins and peptides from serum as an effective sample preparation for detection and idetification of biomarkers by mass spectrometry. Proteomics 4: 1195-1203.

Chutipanyaporn, P., Kruawan, K., Chupeerach, C., Santivarangkna, C. dan Suttisansanee, U. (2014). The effect of cooking process on antioxidant activities and total phenolic compounds of five colored beans. Food and Applied Bioscience Journal 2(3): 183-191.

Du, Y., Wu, D., Wu, Q. dan Guan, Y. (2014). Quantitative evaluation of peptide-extraction methods by HPLCtriple-quad MS-MS. Analytical and Bioanalytical Chemistry 407(6): 1595-605.

Fan, J., Hu, X., Tan, S., Zhang, Y.,Tatsumie, E. dan Lib, L. (2009). Isolation and characterisation of a novel angiotensin I-converting enzyme-inhibitory peptide derived from douchi, a traditional Chinese fermented soybean food. Journal of Science Food and Agriculture 89: 603-608.

Fling, S.P. dan Gregerson, D.S. (1986). Peptide and protein molecular weight determination by electrophoresis using a high molarity Tris buffer system without urea. Analytical Biochemistry 155: 83-88.

Gekko, K., Ohmae, E., Kameyama, K. dan Takagi, T. (1998). Acetonitrile-protein interactions: amino acid solubility and preferential solvantion. Biochimica et Biophysica Acta 1(387): 195-205.

Gibbs, B.F., Zougman, A., Masse, R. dan Mulligan, C. (2004). Production and characterization of bioactive peptides from soy hydrolysate and soy-fermented food. Food Research International 37: 123-131.

Kawashima, Y., Fukutomi, T., Tomonaga, T., Takahashi, H., Nomura, F., Maeda, T. dan Kodera, Y. (2010). Highyield peptide-extraction method for the discovery of subnanomolar biomarkers from small serum samples. Journal of Proteome Research 9(4): 1694-1705.
Handoyo, T. dan Morita, N. (2006). Structural and functional properties of fermented soybean(tempeh) by using Rhizopus oligosporus. Intemational Joumal of Food Properties 9: 347-355.

Ichsani, N. (2013). Karakteristik Fisikokimia dan Sifat Fungsional Tempe yang Dihasilkan dari Berbagai Varietas Kedelai. Skripsi. Departemen Ilmu dan Teknologi Pangan. Institut Pertanian Bogor, Bogor.

Kay, R., Barton, C., Ratcliffe, L., Matharoo-Ball, B., Brown, P., Roberts, J., Teale, P. dan Creaser, C. (2008). Enrichment of low molecular weight serum proteins using acetonitrile precipitation for mass spectrometry based proteomic analysis. Rapid Communication in Mass Spectrometry 22(20): 3255-3260.

Mahmod, M.H., Ferial, M., Abu-Salema., El-Kalyoubib, M.H. dan Gibrielb, A.Y. (2011). Bioactive compounds of fermented soybean natto as antioxidant and antimicrobial agents. Journal of. Food and Dairy Science 2(1): 59-70.

Matsuo, M. (2006). Chemical components palatability antioxidant activity and antimutagenicity of oncom, miso using a mixture of fermented soybeans and okara with Neuspora intermedia. Journal of Nutritional Science and Vitaminology 52: 216-222.

Nakahara, T., Yamaguchi, H. dan Uchida, R. (2012). Structure on the stability of various peptidases during peptideenriched soy sauce fermentation. Journal of Bioscience and Bioengineering 113(3): 355-359.

Natarajan, S.S., Krishnan, H.B., Laksman, S. dan Garret, W.M. (2009). Extraction of soybean seed low abundant proteins. Analytical Biochemistry 394: 259-268.

Pace, C.N., Trevino, S., Prabhakaran, E. Dan Scholtz, J.M. (2004). Protein structure, stability and solubility in water and other solvents. Philosophical Transactions of the Royal Society of London B, Biological Science 359(1448): 1225-1235.

Singh, B.P., Vij, B. dan Hati, S. (2014). Functional significance of bioactive peptides derived from soybean. Peptides 54: 171-179.

Shon, M.Y., Lee, J., Choi, J.H., Choi, S.Y., Nam, S.H., Seo, K.I., Lee, S.W., Sung, N.J. dan Park, S.K. (2007). Antioxidant and free radical scavenging activity of methanol extract of chungkukjang. Journal of Food Composition and Analysis 20: 113-118.

Soim, A. (2013). Hari tempe sedunia. http://bkp.pertanian. go.id. [ 25 April 2016]. 
Suyantohadi, A. (2016). Kebutuhan Import Kedelai Indonesia telah di peringkat on. 2 Tertinggi Dunia. http://attempe. com [26 Juli 2016].

Tirumalai, R.S. (2003). Characterization of the low molecular weight human serum proteome. Molecular and Cellular Proteomics 2(10): 1096-1103.

Turkmen, N., Sari, F. dan Velioglu, S. (2005). The effect of cooking methods on total phenolics and antioxidant activity of selected green vegetables. Food Chemistry 93: 713-718.

Wang, L., Saito, M., Tatsumi, E. dan Li, L. (2003). Antioxidative and angiotensin I-converting enzyme inhibitory activities of sufu (fermented tofu) extracts. Japan Agricultural Research Quarterly 37(2): 129-132.
Wang, W., Vignani, R., Scali, M. dan Cresti, M. (2006). A universal and rapid protocol for protein extraction from recalcitrant plant tissues for proteomics analysis. Electrophoresis 27: 2782-2786.

Zhang, Jian-Huang., Tatsumi, E., Din, Chang-He. dan Li, LiTe (2006).Angiotensin I-converting enzyme inhibitory peptides in douchi, a Chinese traditional fermented soybean product. Food Chemistry 98(2006): 551-557.

Zhu, Y.P., Fan, J.F., Cheng, Y.Q. dan Li, L.T. (2008). Improvement of the antioxidant activity of Chinese traditional fermented okara (Meitauza) using Bacillus subtilis B2. Food Control 19: 654-661. 